\title{
ZASADY KATEGORYZACJI NAZW ATRYBUTYWNYCH SUBIEKTÓW CZYNNOŚCI FUNKCJONUJĄCYCH W LEKSYCE GWAROWEJ
}

\author{
Beata Gala-Milczarek \\ Uniwersytet Łódzki \\ ORCID: 0000-0001-7411-7568
}

\begin{abstract}
Streszczenie. Tekst jest propozycją nowego ujęcia nominalnych dewerbatywów gwarowych o właściwościach atrybutywnych, powszechnie dotychczas kategoryzowanych, głównie ze względów formalnych, w obrębie kategorii nazw osobowych subiektów czynności.

Zaproponowana systematyka atrybutywnych nazw subiektów czynności oparta została na dwóch kryteriach: formalnym, przyjmujacym verbum za podstawę procesu derywacyjnego kategorii wyjściowej - nazw subiektów czynności, i semantycznym, które relacjom motywacyjnym nadaje atrybutywny charakter. Relacje te mogą być wyrażone w formie parafrastycznej: 'ten, kto lubi, potrafi, ma zwyczaj', mogą wynikać z atrybutywnego znaczenia czynności motywującej bądź mogą być formułowane i wnoszone do jednostki derywowanej przez wykładnik formalny funkcji atrybutywnej.
\end{abstract}

Słowa klucze: dialektologia, słowotwórstwo, kategoria słowotwórcza

Leksyka gwarowa dostarcza licznych przykładów formacji rzeczownikowych o motywacjach czasownikowych, które wyrażają subiekta czynności o typowych tylko dla niego właściwościach, jawiących się w charakteryzujących go działaniach, stylu bycia, skłonnościach czy zachowaniu. Przyczyn tego zjawiska doszukiwać się należy w specyfice słownictwa ludności wiejskiej, która przejawia wyraźną tendencję do nazywania przy jednoczesnym znamionowaniu czy wartościowaniu. Bogactwo tego typu formacji wiąże się $\mathrm{z}$ wykorzystaniem $\mathrm{w}$ procesach derywacyjnych różnorodnych pod względem znaczeniowym podstaw słowotwórczych, często nacechowanych stylistycznie, głównie pejoratywnie, które wnoszone do derywatów nadają im wymiar atrybutywny niejednokrotnie wzmacniany poprzez odpowiednie sufiksy, por. -us w: ciekus, chlajus, wycierus.

Ze względów formalnych derywaty tego typu klasyfikowane są najczęściej w obszarze wartości kategorialnej nazw wykonawców czynności, bez rozstrzygania o funkcji semantycznej czynności je motywujących. Przykłady takiej kategoryzacji znajdujemy w opracowaniach dotyczących polszczyzny 
zarówno ogólnej ${ }^{1}$, jak i gwarowej². Sygnały o potrzebach wprowadzenia modyfikacji w zakresie kategoryzacji niektórych derywatów czynnościowych o wartości kategorialnej nazw subiektów odczytujemy już w pracach Witolda Doroszewskiego, Henryka Gaertnera czy Romana Laskowskiego. Autorzy opisów słowotwórczych wyraźnie wskazują na odrębność nazw o charakterze skłonnościowym, a także ustalanych w oparciu o podstawy nacechowane stylistycznie, wyrażające cechy werbalne, oraz nazw powoływanych na podstawie czasowników dźwiękonaśladowczych bądź które w procesach derywacyjnych wykorzystano w znaczeniu przenośnym.

W odniesieniu do formacji na -ek Doroszewski pisze, iż ,,[n]azwy wykonawców czynności (nomina agentis) stanowią pewną odmianę rzeczowników atrybutywnych, ponieważ są to w gruncie rzeczy nazwy nosicieli cech werbalnych"3. W omówieniu zaś derywatów dewerbalnych na -ała Gaertner przyjmuje, że ,[s]ą to rzeczowniki prawie wyłącznie czynnikowe, oznaczające osoby według przejawu, znanego co do sposobu odbywania się. Charakterystykę osób w tych nazwach stanowi zatem sposób wykonywania pewnych czynności, a nie tylko sama czynność"4.

Natomiast wśród uwag zamieszczonych przez Romana Laskowskiego czytamy m.in.: „Nomina agentis na $-a k[\ldots]$ mają z reguły pejoratywny charakter. Najczęściej wynika to ze znaczenia czasownika podstawowego, którym w większości wypadków bywa czasownik onomatopeiczny"5.

\footnotetext{
$1 \quad$ Patrz Z. Klemensiewicz, T. Lehr-Spławiński, S. Urbańczyk, Gramatyka historyczna języka polskiego, Warszawa 1964; R. Grzegorczykowa, J. Puzynina, Stowotwórstwo współczesnego języka polskiego, Warszawa 1979; R. Grzegorczykowa, Zarys słowotwórstwa polskiego. Stowotwórstwo opisowe, Warszawa 1981; eadem, Gramatyka wspótczesnego języka polskiego. Morfologia, Warszawa 1998.

2 Por. M. Szymczak, Gwara Domaniewka i wsi okolicznych w powiecie łęczyckim, Łódź 1961; W. Cyran, Tendencje słowotwórcze w gwarach polskich, Łódź 1977; K. Dejna, Słownictwo ludowe z terenu bylych województw kieleckiego i łódzkiego, „Rozprawy Komisji Językowej ŁTN" 1989/1990, t. 20-31; H. Górnowicz, Formanty przyrostkowe rzeczowników w gwarach malborskich, cz. I, „Rozprawy Komisji Językowej ŁTN”, t. 13, s. 13-53; cz. II, „Rozprawy Komisji Językowej ŁTN”, t. 16, s. 53-82; T. Malec, Budowa stowotwórcza rzeczowników i przymiotników w gwarze wsi Rachanie pod Tomaszowem Lubelskim, Wrocław 1976; G. Habrajska, Typy stowotwórcze rzeczowników w gwarze wsi Mastońskie (woj. częstochowskie), „Rozprawy Komisji Językowej ŁTN” 1989/1990, t. 34, s. 87-110.

W. Doroszewski, Monografie stowotwórcze I. Formacje z podstawowym - $k$ - $w$ części sufiksalnej, „Prace Filologiczne” 1928, t. 13, s. 28, patrz też s. 203-207 oraz idem, Monografie stowotwórcze II. Formacje z podstawowym -l-w części sufiksalnej, „Prace Filologiczne” 1929 , t. 14 , s. 63 .

4 H. Gaertner, Gramatyka wspótczesnego języka polskiego, cz. III. 1. Stowotwórstwo, Lwów-Warszawa 1934, s.278, patrz też s. 305, 331.

$5 \quad$ R. Laskowski, Derywacja rzeczowników w dialektach laskich, cz. II, Wrocław 1971, s. 15.
} 
Podobne spostrzeżenia notuje Michał Sajewicz, który wśród nazw subiektów czynności wskazuje te, które mają charakter ekspresywny, skłonnościowy ${ }^{6}$.

Równie złożoną sytuację spotykamy w pracach poświęconych nazwom atrybutywnym. Określane także mianem nazw znamionujących ${ }^{7}$, nosicieli cech czy właściwości ${ }^{8}$ obejmują nazwy o formalno-znaczeniowych powiązaniach z podstawami przymiotnikowymi / imiesłowowymi i rzeczownikowymi, które definiują desygnat ze względu na jego przymiot, wyróżnik. Przyjęcie za nadrzędne kryterium semantycznego pozwoliło na rozszerzenie rozumienia atrybutu, jego właściwości również na przejaw działania, w związku z którym desygnat jest nazywany. W rezultacie nomina attributiva uległy znacznemu zróżnicowaniu formalnemu, a struktury derywowane wiązano z różnymi pod względem gramatycznym podstawami derywacyjnymi - zarówno przymiotnikowymi - wskazującymi cechę, rzeczownikowymi - wyrażającymi atrybut, jak i czasownikowymi - wyrażającymi cechy werbalne. Ponadto uwzględniane bywają nazwy niepodzielne słowotwórczo, nazwy przymiotnikowe i związki frazeologiczne. $Z$ ujęciem takim spotykamy się w pracy Ireny Szczepankowskiej Nomina attributiva $w$ gwarze tomżyńskiej. Studium leksykalno-stowotwórcze $e^{9}$, która dostrzega bogactwo i różnorodność gwarowych nazw atrybutywnych, przy jednoczesnych utrudnieniach w konsekwentnej ich klasyfikacji. By zatem uniknąć, jak pisze, selekcji nazw według apriorycznie przyjętych kryteriów formalnych, w proponowanym omówieniu uwzględnia pełny, zgromadzony materiał leksykalny ${ }^{10}$. Odsłania jednocześnie możliwości wielostronnej jego interpretacji słowotwórczej, a włączenie w tok omówienia rzeczowników dewerbalnych stanowi przesłankę do potraktowania tej klasy derywatów jako odrębnej kategorii słowotwórczo-semantycznej i wyprowadzenia jej z obszaru wartości kategorialnej nazw subiektów czynności, procesów i stanów. W pełni uzasadnione wydają się zatem próby wskazania w opisach słowotwórczych jako niezależnej odrębnej kategorii nazw atrybutywnych subiektów czynności bądź usytuowania jej, jak czyni to Renata

\footnotetext{
$6 \quad$ M. Sajewicz, Derywacja sufiksalna osobowych nazw subiektów w nadnarwiańskich gwarach białoruskich Białostocczyzny, Lublin 2002, s. 131, 136, 163-165, 173, 179-183, 200-207, 218-220, 225, 226-227, 259-261, 267-268, por. też R. Grzegorczykowa, J. Puzynina, op. cit., s. 90, 91, 93, 114, 215-216, 223, 224; B. Gala-Milczarek, Budowa stowotwórcza rzeczowników w gwarach piotrkowskich, Łódź 2009, s. 87-92, 93-95; eadem, Czynnościowy charakter derywatów rzeczownikowych w gwarach piotrkowskich, „Rozprawy Komisji Językowej ŁTN”, 2009(a), t. 14, s. 72-73.

$7 \quad$ Patrz Z. Klemensiewicz, T. Lehr-Spławiński, S. Urbańczyk, op. cit., s. 200-202.

8 R. Grzegorczykowa, Gramatyka ..., s. 416-421, 440-441.

9 I. Szczepankowska, Nomina attributiva w gwarze łomżyńskiej. Studium leksykalno-słowotwórcze, Białystok 1998.

10 Op. cit., s. 22.
} 
Marciniak-Firadza, w tzw. „pasie przejściowym między kategorią nazw wykonawców czynności a kategorią nazw atrybutywnych" "11. Przekonuje o tym przede wszystkim różnorodność formalna nazw atrybutywnych, dla których z punktu widzenia słowotwórstwa funkcjonalnego kryterium semantyczne wydaje się niewystarczające.

$\mathrm{Na}$ gruncie polszczyzny ogólnej nazwy (subiektów) nosicieli cech czy właściwości określone zostały mianem klasy paralelnej do klasy nazw subiektów czynności, procesów i stanów przy jednoczesnym wskazaniu wspólnych obu kategoriom wykładników formalnych typu: $-a c z,-a k,-a r z,-e c,-a$, -ik/-yk, -och, (por. wyjadacz, garłacz, żebrak, zębak, łgarz, rutyniarz, ryjec, golec, ochrona, niezdara, łazik, niewdzięcznik, śpioch, tluścioch ${ }^{12}$.

Za decydujący głos w kwestii odróżniania derywatów o wartości kategorialnej nazw atrybutywnych subiektów czynności od nazw subiektów czynności przyjąć można opinię Wacława Cockiewicza, wyrażoną w tekście Jak odróżnić działacza od nosiciela cechy ${ }^{13}$. Najprostszym kryterium wydaje się wyraźne określenie, kiedy czynność wykonywana przez nazywany desygnat jest działaniem celowym, świadomym, zamierzonym, kiedy natomiast postrzegana jest jako atrybut, właściwość przejawiana w czynności, w związku z którą desygnat często jest także oceniany. Odpowiednio konstruowane parafrazy słowotwórcze nie tylko służą ujawnieniu podstaw derywacyjnych (tych funkcjonujących w gwarach), ale odsłaniają specyfikę relacji semantycznych tychże podstaw względem jednostek derywowanych. Cockiewicz zasady tych relacji przedstawia w oparciu o właściwe nazwom subiektów i nazwom subiektów atrybutywnych struktury predykatowo-argumentowe.

W przypadku nazw wykonawców czynności zamierzonych, celowych, struktury odpowiadają relacjom jednego argumentu (subiekta - ktoś, ten, kto) z predykatem (robi (coś), wykonuje czynność), a role argumentów i predykatów znajdują odzwierciedlenie w strukturze powoływanych formacji nominalnych. W nazwach atrybutywnych te relacje są rozbudowane. Mamy bowiem do czynienia $\mathrm{z}$ argumentem (subiekta - ktoś, ten, kto) i z dwoma predykatami (1 - lubi, potrafi, ma zwyczaj), (2 - robi (coś), wykonuje czynność), przy czym tylko jeden z nich zostaje formalnie przeniesiony do jednostki derywowanej. Jak pisze Cockiewicz: ,[J]eżeli w strukturze znaczenia kategorialnego derywatu argument, będący semantycznym korelatem formantu słowotwórczego, nie wchodzi w bezpośredni stosunek z predykatem stanowiącym korelat podstawy słowotwórczej, lecz ten ostatni zdominowany jest przez inny

\footnotetext{
11 R. Marciniak-Firadza, Nazwy osobowych wykonawców czynności w gwarach małopolsko-mazowieckiego pogranicza językowego. Studium słowotwórczo-leksykalne, cz. I, II, Łódź 2013, s. 36.

12 R. Grzegorczykowa, Gramatyka..., s. 400-405, 418-421, 440-441.

13 W. Cockiewicz, Jak odróżnić działacza od nosiciela cechy, [w:] Studia Językoznawcze. Dar przyjaciót i uczniów dla Zofii Kurzowej, red. Z. Cygal-Krupa, Kraków 2001, s. 53-62.
} 
(modalny) predykat, niemający w strukturze formalnej wyrazu osobnego korelatu, to taki derywat nie należy do kategorii nomina agentis, lecz do kategorii nomina attributiva"14.

Przyjęcie takiego stanowiska daje możliwość w miarę klarownego usystematyzowania pod względem formalnosemantycznym nazw atrybutywnych motywowanych znaczeniami czynności. Zgodnie $\mathrm{z}$ takimi też wytycznymi przeprowadzona została systematyka dewerbalnych nazw subiektów atrybutywnych funkcjonujących w gwarach północnomałopolskich i przyległych ${ }^{15}$. Za podstawę źródłową przyjęto leksykę zgromadzoną przez Karola Dejnę w Stownictwie ludowym z terenu byłych województw kieleckiego i łódzkiego ${ }^{16}$. Analiza materiału pozwoliła na wyselekcjonowanie 267 formacji o znaczeniu atrybutywnego osobowego i nieosobowego subiekta czynności. Ustalone dla nich znaczenia podstawowe znalazły potwierdzenie w leksyce gwarowej. $\mathrm{W}$ pojedynczych jedynie przykładach podstawy poddano rekonstrukcji, por. kutwa: kutwić.

W wyniku interpretacji słowotwórczej form derywowanych wskazano 67 formantów łączonych głównie z atrybutywnymi podstawami werbalnymi. Do najliczniejszych należą derywaty na: -acz, -uch, $-k a,-a k,-e k,-n i k,-a ł a,-u s$. Często powoływane są nazwy w wyniku derywacji paradygmatycznej - dwurodzajowe na $-a$ oraz wyłącznie męskie $\mathrm{z}$ formantem zerowym także sufiksalne na: -ocha, -al, -arz. Nieliczne, często pojedyncze przykłady, tworzone są przez formanty: -ca, -ica, -nica, -awica, -erca, -ec, -elec, -aniec, -eniec, -awiec, -icz, -ach, -acha, -icha, -ucha, -och, -ciuch, -aluch, -czuch, -ajda, -ega, -uga, -aj, -ulka, -ałka, -ułka, -onka, -arka, -awka, -niak, -anek, -el, -iciel, -ula, -at, -uła, -ajło, -inal-yna, -elina, -izna, -iny (pl.t.), -ynia, -oń, -yń, -ator/-atór, -erz, -sa, -as, -tus, -isz, -uś, -ot, -ota, -awa.

Ustalono także, że gwarowe deverbalne attributiva tworzą cztery klasy semantyczne:

1) stanowią nazwy odnoszące się do desygnatów osobowych, pitracha 'kobieta źle gotująca posiłki', sprzeka 'człowiek, który lubi się sprzeczać', latawiec 'człowiek lubiący się włóczyć, próżnować', glamak 'człowiek jedzący powoli, mlaskając', leżak 'człowiek, który ciągle leży, śpi', grzebek 'niezdara', marudnik 'człowiek, który marudzi', gęgal 'jąkała', smarkula 'brudna dziewczyna', rykata 'człowiek pokrzykujący';

2) rzeczowniki nazywające wszelkie istoty świata fauny, por. kwoka 'kura siedząca na jajach i wodząca kurczęta', cykacz 'konik polny', derkacz 'chruściel', mlaskacz 'pliszka', gonicha 'krowa w okresie popędu', świstka 'koń, który kopie', piejak 'kogut', mruczek 'kot';

\footnotetext{
14 Op. cit., s. 59.

15 B. Gala-Milczarek, Czynnościowy charakter...

16 K. Dejna, op. cit.
} 
3) nazwy roślin, por. powójka 'powój, bluszcz', smycza 'ostra trawa', pławucha 'trawa na wodzie', lepka 'thuste, lepkie zielsko rosnące w lnie', trzaska 'rodzaj rośliny', smrodynia 'czeremcha';

4) nazwy przedmiotów, por. pylica 'piaszczysty grunt', parzucha 'kapusta z kartoflami', kopciuch 'lampa', chlebotka 'zepsute jajo', klapotka 'stary but', skwierczka 'skwarek', trząska 'galaretka z wygotowanych kości i mięsa', smrodziny 'negatywnie o perfumach'.

Znaczenia czynności, w związku z którymi powoływane są rzeczowniki atrybutywne, wyrażane są przez czasowniki niedokonane, nazywające właściwości stałe, powtarzane. $\mathrm{W}$ pojedynczych przykładach notuje się wyłącznie formalny związek z podstawami dokonanymi, ten weryfikowany jest w omówieniach parafrastycznych, por. oszukaniec 'ten, kto często oszukuje, oszust': oszukać, udaniec 'człowiek, który udaje': udać, ochlapus 'pijak': ochlapać (się) 'spić się'.

Jak już wspomniano, istotne w ustalaniu znaczenia atrybutywnego nazywanego desygnatu jest znaczenie czynności motywującej. Ta, szczególnie na gruncie gwarowym, jest nośnikiem silnego ładunku stylistycznego, który wnoszony do treści derywatu decyduje o jego atrybutywnym charakterze, por. -a: maruda 'człowiek, który marudzi': marudzić; mazia 'małe dziecko ciągle płaczące': mazać (się) 'płakać', sprzeka 'człowiek, który lubi się sprzeczać': sprzeczać (się), wachla 'człowiek, który niepotrzebnie dużo mówi': wachłać 'dużo mówić niepotrzebnie', zadziora 'człowiek, który lubi się bić z innymi': zadzierać 'zaczepiać', zapieka 'człowiek, który dokucza innym': zapiekać 'dokuczać', -ca: bluźnierca: bluźnić; szyderca: szydzić, -ec: wyjec: wyć 'często płakać', -acz: babracz: babrać (się) 'bawić się, grzebać w błocie', cherlacz 'człowiek, który często choruje': cherlać 'chorować', chlacz: chlać 'pić wódkę', ciekacz 1) ‘człowiek włóczący się',2) 'zwierzę szukające pożywienia poza wyznaczonym pastwiskiem': ciekać, pyskacz: pyskować; smarkacz: smarkać, szczekacz 'pyskacz': szczekać 'pyskować', -ak: babrak 'dziecko, które lubi bawić się, babrać w błocie': babrać (się), ćpak 'człowiek, który dużo je': ćpać 'jeść żarłocznie i głośno, żreć', glamak 'człowiek jedzący powoli, mlaskając': glamać, paprak 'człowiek, który źle wykonuje swoją pracę': paprać 'źle pracować', -ek: dtubek: dłubać 'robić powoli', dulczek: dulczyć 'marudzić', grzebek 'niezdara': grzebać (się), -nik: jazgocznik 'krzykacz': jazgotać, lamentnik 'człowiek, który dużo narzeka, z niczego nie jest zadowolony': lamentować, latownik 'kobieciarz, mężczyzna, który biega za spódniczkami': latować (się), marudnik 'człowiek, który marudzi': marudzić, pomstownik 'osobnik nadużywający przekleństw, skłonny do złorzeczeń': pomstować, psotnik: psocić; -arz: kpiarz: kpić, łgarz 'kłamca': łgać, machlarz 'oszust': machlować 'oszukiwać', paskudziarz 'pozostawiajacy po sobie brud': paskudzić.

W wielu przypadkach znaczenie atrybutywnej czynności podstawowej potęgowane jest przez formanty wnoszące silny ladunek ekspresywny - 
pejoratywny ${ }^{17}$. Należą do nich: -ach, -acha, -icha, -uch, -al, -el, -ula, -ała, -ajło, -uła, -us czy -ocha i -och, który zdaniem Gertnera, kształtuje nazwy charakterystyczne i czynnikowe, a wśród nich głównie nazwy o znaczeniu karykaturalnym ${ }^{18}$, por. -ach: srach 'wyzwisko kierowane do małego dziecka': srać; -acha: pierdacha 'człowiek zanieczyszczający powietrze': pierdzieć; -icha: gonicha 1) 'krowa w okresie popędu', 2) 'kobieta uganiająca się za mężczyznami': gonić; -och: pierdzioch 'człowiek psujący powietrze': pierdzieć; -ocha: siajocha 'kobieta, która niezgrabnie chodzi, szurając nogami o ziemię': siajać 'chodzić ciężko, szurając nogami, tłuc się'; -uch: mazuch 'beksa, mazgaj, płaksa': mazać (się) 'płakać'; -al: chrapal 'człowiek, który chrapie': chrapać; -el: pierdziel 'człowiek psujący powietrze': pierdzieć; śmierdziel 'istota śmierdząca': śmierdzieć; -ula: pyskula 'kobieta pyskata, plotkara': pyskować; -ajło: grzebajło 'człowiek, niemogący wykonać na czas prac w gospodarstwie': grzebać (się); jąkajło 'człowiek, który się jąka': jąkać (się); krzykajło: krzykać 'pokrzykiwać; -ała: bazgrała: bazgrać; -uła: gaduła 'człowiek, który dużo mówi': gadać; -us: chlajus: chlaj-, chlać 'pić wódkę'; legus 'człowiek, który ciągle leży, śpi': leżeć.

Natomiast formant jako wyłączny wykładnik wartości atrybutywnej wskazano w derywatach typu: -ega: robiega 'partacz': robić; -uś: śpiewuś 'ktoś, kto lubi śpiewać': śpiewać; -och: śpioch: śpi, spać czy modloch 'obłudnik chodzący ciągle do kościoła': modlić (się).

Zaproponowana systematyka atrybutywnych nazw subiektów czynności została oparta na dwóch kryteriach: formalnym, przyjmującym verbum za podstawę procesu derywacyjnego kategorii wyjściowej - nazw subiektów czynności, i semantycznym, które relacjom motywacyjnym nadaje atrybutywny charakter. Te mogą być wyrażone w formie parafrastycznej: 'ten, kto lubi, potrafi, ma zwyczaj', mogą wynikać z atrybutywnego znaczenia czynności motywującej bądź mogą być formułowane i wnoszone do jednostki derywowanej przez wykładnik formalny funkcji atrybutywnej. Wyodrębnienie tej wartości kategorialnej w systemie słowotwórczym wydaje się szczególnie uzasadnione w odniesieniu do leksyki gwarowej, która wyróżnia się bogactwem formacji znamionujących, wartościujących. Te z kolei w rzeczywistości gwarowej często służą także identyfikacji.

\section{BIBLIOGRAFIA}

Cockiewicz Wacław. 2001. Jak odróżnić działacza od nosiciela cechy. W: Studia Językoznawcze. Dar przyjaciót i uczniów dla Zofii Kurzowej. Red. Cygal-Krupa Z. Kraków: UNIWERSITAS: 53-62.

17 Patrz S. Grabias, O ekspresywności języka. Ekspresja a stowotwórstwo, Lublin 1981, s. 73.

18 H. Gaertner, op. cit., s. 331. 
Cyran Władysław. 1977. Tendencje słowotwórcze w gwarach polskich. Łódź: Wydawnictwo ŁTN.

Dejna Karol. 1974-1985. Stownictwo ludowe z terenu bytych województw kieleckiego i łódzkiego. „Rozprawy Komisji Językowej ŁTN” t. 20-31.

Dejna Karol. 1989/1990. Stowotwórstwo sufiksalne gwary czeskiej Kucowa. „Rozprawy Komisji Językowej ŁTN" t. 36: 19-68.

Doroszewski Witold. 1928. Monografie stowotwórcze I. Formacje z podstawowym -kw części sufiksalnej. „Prace Filologiczne” t. 13: 1-261.

Doroszewski Witold. 1929. Monografie słowotwórcze II. Formacje z podstawowym -lw części sufiksalnej. „Prace Filologiczne” t. 14: 34-85.

Gaertner Henryk. 1934. Gramatyka współczesnego języka polskiego, cz. III. 1. Słowotwórstwo. Lwów-Warszawa: Książnica - Atlas.

Gala-Milczarek Beata. 2009. Budowa słowotwórcza rzeczowników w gwarach piotrkowskich. Łódź: Wydawnictwo Uniwersytetu Łódzkiego.

Gala-Milczarek Beata. 2009(a). Czynnościowy charakter derywatów rzeczownikowych w gwarach piotrkowskich. „Rozprawy Komisji Językowej ŁTN” t. 54: 57-76.

Gala-Milczarek Beata. 2016. Czynnościowy charakter derywatów rzeczownikowych $w$ gwarach pólnocnomałopolskich i przyległych. Studium morfologiczno-leksykalne. Łódź: Wydawnictwo Uniwersytetu Łódzkiego.

Górnowicz Hubert. 1967, 1968. Formanty przyrostkowe rzeczowników w gwarach malborskich. cz. I. „Rozprawy Komisji Językowej ŁTN” t. 13: 13-53; cz. II. „Rozprawy Komisji Językowej ŁTN” t. 16: 53-82.

Grabias Stanisław. 1981. O ekspresywności języka. Ekspresja a stowotwórstwo. Lublin: Wydawnictwo Lubelskie.

Grzegorczykowa Renata, Puzynina Jadwiga. 1979. Stowotwórstwo wspótczesnego języka polskiego. Warszawa: Państwowe Wydawnictwo Naukowe.

Grzegorczykowa Renata. 1998. Gramatyka współczesnego języka polskiego. Morfologia. Warszawa: PWN .

Grzegorczykowa Renata. 1981. Zarys stowotwórstwa polskiego. Stowotwórstwo opisowe. Warszawa: PWN.

Habrajska Grażyna. 1989/1990. Typy słowotwórcze rzeczowników w gwarze wsi Masłońskie (woj. częstochowskie). „Rozprawy Komisji Językowej ŁTN” t. 34: 87-110.

Klemensiewicz Zenon, Lehr-Spławiński Tadeusz, Urbańczyk Stanisław. 1964. Gramatyka historyczna języka polskiego. Warszawa: PWN.

Laskowski Roman. 1971. Derywacja rzeczowników w dialektach laskich. cz. II. Wrocław: Zakład Narodowy im. Ossolińskich.

Malec Tadeusz. 1976. Budowa słowotwórcza rzeczowników i przymiotników $w$ gwarze wsi Rachanie pod Tomaszowem Lubelskim. Wrocław: Zakład Narodowy im. Ossolińskich.

Marciniak-Firadza Renata. 2013. Nazwy osobowych wykonawców czynności w gwarach małopolsko-mazowieckiego pogranicza językowego. Studium słowotwórczo-leksykalne. cz. I, II. Łódź: Wydawnictwo Uniwersytetu Łódzkiego.

Sajewicz Michał. 2002. Derywacja sufiksalna osobowych nazw subiektów w nadnarwiańskich gwarach białoruskich Białostocczyzny. Lublin: Wydawnictwo UMCS.

Szczepankowska Irena. 1998. Nomina attributiva $w$ gwarze łomżyńskiej. Studium leksykalno-słowotwórcze. Białystok: Wydawnictwo Trans Humana.

Szymczak Mieczysław. 1961. Gwara Domaniewka $i$ wsi okolicznych w powiecie tęczyckim. Łódź: Zakład Narodowy im. Ossolińskich. 


\title{
PRINCIPLES OF CLASSIFICATION OF THE ATTRIBUTIVE NAMES OF THE SUBJECTS OF ACTIVITY USED IN THE LEXIS OF VERNACULARS
}

Summary. This study provides a proposition of a new way of adoption of the nominal verbal nouns used in vernaculars, which have attributive properties and, mostly for formal reasons, have been widely classified until now as the personal names of the subjects of activity.

The systematics of the attributive names of the subjects of activity which has been proposed herewith is based on two criteria: the formal one, according to which the verb is the base of the derivational process of the output category - of the names of the subjects of activity, and the semantic one, which imparts attributive character to the motivational relations. They might be expressed in a circumlocutory form: 'these, who likes, can, has a custom' and might either result from the attributive meaning of the motivational activity or be formed and included in the derivatised word through the formal marker of the attributive function.

Key words: dialectology, word formation, derivative category

\section{ПРИНЦИПИ КАТЕГОРИЗАЦІЇ НАЗВ АТРИБУТИВНИХ ВИКОНАВЦІВ ДІЇ У ДІАЛЕКТНІЙ ЛЕКСИЦІ}

\begin{abstract}
Анотація. Текст містить пропозицію нового підходу до діалектних атрибутивних девербативів, які зазвичай категоризують, зокрема через формальні причини, в межах категорії назв виконавців дії.

Запропонована класифікація атрибутивних назв виконавців дії грунтується на двох критеріях: формальному, за яким дієслово вважається основою дериваційного процесу вихідної категорії назв виконавців дії, та семантичному, що мотиваційним відношенням надає атрибутивного характеру. Ці відношення можуть бути реалізовані у парафрастичній формі: «той, хто любить, вміє, має звичку», можуть випливати 3 атрибутивного значення дії або їх можна сформулювати та внести у похідну одиницю за допомогою формального показника атрибутивної функції.
\end{abstract}

Ключові слова: діалектологія, словотвір, словотвірна категорія 
